\title{
Health Website Success: User Engagement in Health-Related Websites
}

\author{
https://doi.org/10.3991/ijim.v11i6.6959 \\ Jehad Imlawi \\ Al Al-Bayt University, Mafraq, Jordan \\ imlawi@aabu.edu • jo
}

\begin{abstract}
Increasing number of online users are accessing health-related websites on the Internet, and rely on it to get answers for their health questions. Health care providers try to develop websites that focus on the users' needs. One of the key factors, to develop users' driven health-related websites, is the focus on users' engagement.

This study proposes a research model to investigate what factors are critical to users' engagement in health-related websites. Accordingly, three factors were identified; website usability, website interactivity, and users' perceived quality of health information. Little research has previously explored such a thorough list of factors that affect users' engagement in health-related websites.

240 respondents have participated in an online survey, to test the research model. Results show that the influence of the engagement antecedents, identified by the study, is significant. These factors explain a great percentage of the variance for the engagement. The study is finally concluded by implications for theory and practice.
\end{abstract}

Keywords - website usability, website interactivity, engagement, health information quality, human computer interaction

\section{Introduction}

Research found that online users frequently access health-related websites to search for online health information [1]. Questions posted online, by these users, are considered as beneficial and engaging dialogues. Interactive communication that provide quick and recent responses may also contribute to a sense of online social presence, which may also be perceived as beneficial by online users.

Interactivity has been defined as responsiveness, control, and reciprocity between a website and their users. Interactivity is a type of two-way communication between a user and the website [2]. Significance of website interactivity is well established in IS literature. However, Liu \& Shrum (2002) found that the effect of interactivity on online users' behavior requires more investigations, to generate specific design guidelines for online websites to be more interactive [2].

When online users choose to explore a web environment, they are also choosing to interact with it [3]. Therefore, websites' designers are required to support this interac- 
tion [4]. To this end, practitioners need more insights about the implementation of interactive communication features in their websites. Ariely (2000) argued that most websites are facing the challenge of providing their users with relevant information [14]. This task might be easier when engaging those users in an interactive communication.

The tremendous growth in health-related websites, and its success in providing user-centric services, encouraged more researchers to investigate the different aspects of health-related websites' usability. Website usability defined as the combined effect of several design goals that make a website easy to learn, easy to remember, easy to understand, easy to find and effective to use [5]. Prior literature provided principles and guidelines that practitioners can follow to improve their websites' usability. However, many of these design rules did not go through a systematic test of validation in the literature [6]. Consequently, theoretical and empirical evidences are still needed to better understand the influence of website usability on online user behavior. Moreover, the available guidelines are sometimes not appropriate for all of the different settings. Usability design guidelines for health-related websites, for example, need more investigations by the literature.

Engagement was defined in the literature as the feeling that a system has caught, captured, and captivated user interest [7]. Prior research has focused on the significance of engagement in online settings. However, little research has investigated whether and how engagement in online settings influences users' experience [8]. No previous research has studied antecedents of users' engagement in health-related websites.

Perceived quality of online information refers to the extent to which a user perceives the information, provided by a website, as complete, accurate, current, useful, and relevant [9]. Quality is one of the main challenges that online information face. Sources of online health information have been initially perceived by online users as low reputation sources [10]. However, more studies developed specific criteria that helped in improving users' perception of online health information quality.

This research investigates the impact of website interactivity, website usability, and perceived information quality on users' engagement in health-related websites. The second section of this research presents the literature review and hypotheses building. Third section explains the research methodology, followed by section four that presents the research results. The research is finally concluded with the research implications for theory and practice in section five.

\section{Literature Review and Hypotheses Building}

In this research, we sought to identify the influential factors that have been consistently reported to influence online users' engagement in health-related websites. Engagement was selected in this research, because it is one of the main indicators of website's success. Researchers have proposed that users' engagement in online environment should be a central construct in explaining online users' behavior [11]. 
Engagement is the quality of user's experiences with technology that facilitates more enriching interactions with computer applications [12]. It is the feeling that a system has caught, captured, and captivated user interest [7]. These feeling states are present in every online environment, and are likely to influence the user's experience in this online environment [13].

Concerning the antecedents of engagement in health-related websites, the efforts were to build a thorough list of factors that might affect users' engagement in healthrelated websites. Accordingly, three main factors were identified. First factor is related to the interaction between the health-related website and its users; website interactivity. Second factor is related to the health-related website itself; website usability. The third factor is related to the website content; information quality. Figure 1 shows the research model.

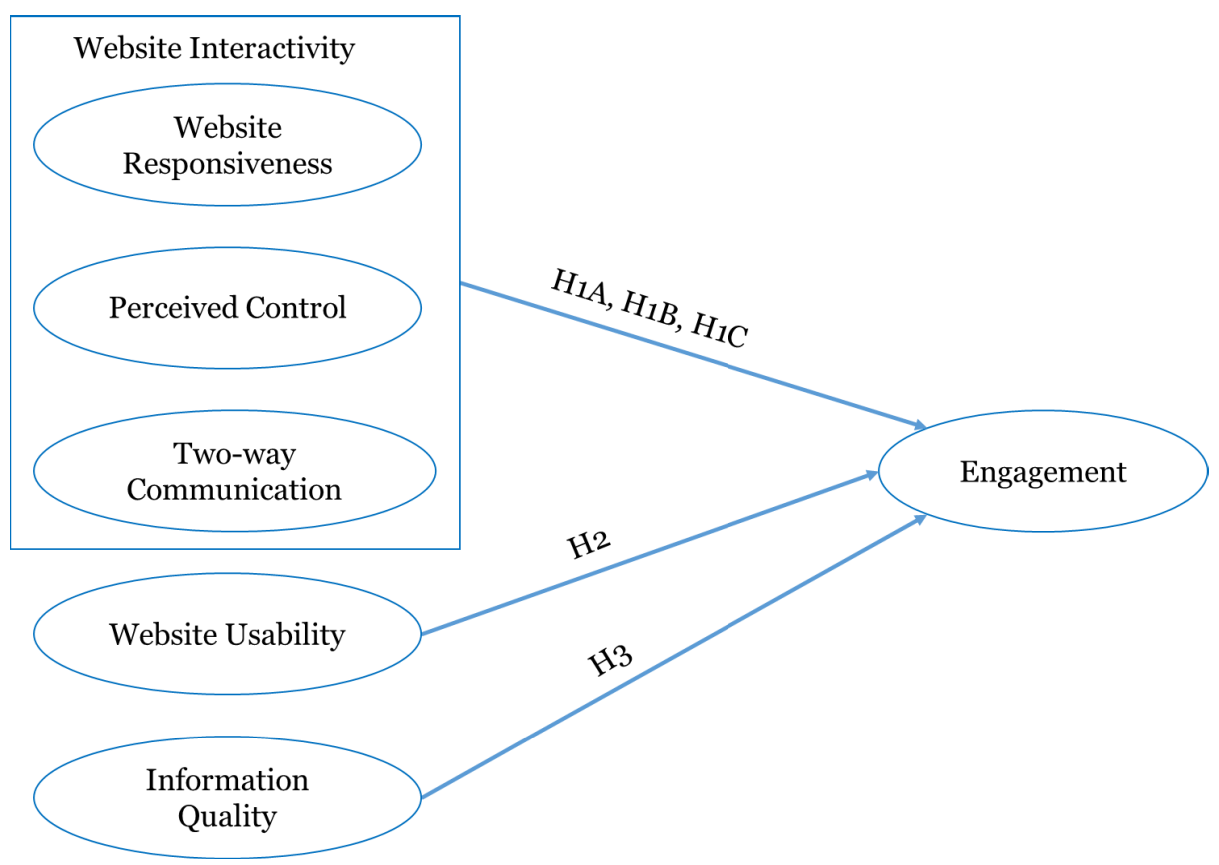

Fig. 1. The Research Model

\subsection{Website Interactivity}

Steuer (1992) defined interactivity as "the extent to which users can participate in modifying the form, or content, of a website in real time" [15]. Although there is no agreed definition of interactivity [16]; Mollen \& Welson (2010) argued that Steuer's definition is the most cited definition of interactivity [17]. Cui, Wang \& Xu (2010, P. 37) defined website interactivity as "the degree to which the consumer perceives the Web site to be controllable, responsive, and synchronic" [18]. 
Website interactivity was proved, in prior research, to improve users' satisfaction [19], flow experience [20, 21], and users' positive attitudes [22]. Website interactivity was also proved to increase the appeal of websites [23, 24]. Wu \& Chang (2005) even found that interactivity improves enjoyment and absorption [20], meaning that interactivity might affect user's engagement in online websites. Thus, user's preference of interactive website is expected to be associated with users' engagement in healthrelated websites.

Mollen \& Welson (2010) argued that there is a degree of consensus in literature on the common components of interactivity; perceived responsiveness, perceived user control, and two-way communication (reciprocity) [17].

Green \& Pearson (2011, P. 186) defined responsiveness as "the presence of feedback to users, and the availability of responses from the site managers" [25]. Responsiveness pertains the willingness, and readiness to provide services [26], and it is the most important element in interactivity [27]. Responsiveness is a key user issue in online environment. Green \& Pearson (2011) found a positive relationship between responsiveness and ease of use [25], and consequently, it is expected to improve the user engagement in a web environment.

Based on the flow theory, users who reported more perceived control on a website, felt more involved when navigating this website [28]. When user have more control in an online experience, they tend to have more flow and pleasure [14]. Similarly, information control theory says that increasing the user control on information flow, improve ability to figure more of the information structure of any information system [14]. Understanding the information structure also suggest that the user would be more engaged in this information system. Cui, Wang \& Xu (2010) argued that perceived control over a website pertains users' participation behavior, and it influences attitude toward a website [18].

Two-way communication, or reciprocity, was defined by Chai, Das \& Rao (2011) as behavioral response to perceived communication [29]. Communicated information must be recent, current, timely, interactive, and up-to-date [30], to be considered as interactive and engaging. Website content should be updated continually to be perceived as performance supportive [31]. This is more significant in the case of health information that loses its weight if it's not interactive, updated and responsive. Han, Min \& Lee (2015) found that immediate feedback is one of the social network sites characteristics that fulfill their users' need [32]. This suggest that feedback communicating behavior influences users' engagement.

H1A: Website responsiveness has a positive impact on users' engagement in this website.

H1B: Users' perceived control over a website has a positive impact on their engagement in this website.

H1C: Users' perceived two-way communication with a website has a positive impact on their engagement in this website. 


\subsection{Website Usability}

Usability is the most traditional concept in human computer interaction (HCI) research. The International Standards Organization (ISO) 9241 standard defines usability as "the extent to which a product can be used by specified users to achieve specified goals with effectiveness, efficiency and satisfaction in a specified context of use" [33]. Rahman \& Ahmed (2013) defined website usability as the combined effect of several design goals that make a website easy to learn, easy to remember, easy to understand, easy to find, and effective to use [34]. Nielsen $(2016$, p.1) argued that "usability is a quality attribute that assesses how easy user interfaces are to use" [35]. Accordingly, he defined usability as learnability, efficiency, memorability, user errors, and satisfaction [35].

Website interface is a primary motivator to use a website, and be engaged in it. The friendlier and usable the interface is, the better the impression of the Website [36]. From both user and business perspectives, a business website can determine the success, or failure of net-enabled businesses [4]. Users are goal-driven; they need to achieve their goal with the least possible efforts [37]. Usable interfaces allow users to achieve goals with less efforts, thus, they are expected to engage those users.

Prior research found that usability can affect online users' behavior, like increasing computer usage. Imalwi \& Gregg (2014) found that increasing computer usage is linked to user engagement [38]. Nantel \& Senecal (2009) suggest that users tend to complete their task on the website when there was no download delay [39], due to high perceived usability. Usability is also a factor that assists in predicting intentions to use a system $[40,41]$. Mummalaneni (2005) found that web design quality affects the emotional state of online users, like arousal and pleasure [42]. Website usability was proven to affect the quality of a website [43, 44], therefore, it may influence users' engagement in a usable website.

Usability concerns capability of managing a system, by memorizing the basic functions, and avoiding errors. It also concerns ease of navigating a website [45]. Manageability, which is one element of usability, increases the general satisfaction of the user [46, 47, 48]. Flavián, Guinalíu, \& Gurrea (2006) found that both usability and satisfaction are directly linked to the website loyalty [45]. Users tend to feel familiar with usable website [46], because usability helps in simplifying transactions, and allowing user to achieve their goals in a simple manner [66]. Thus, we hypothesized that website usability has a positive impact on users' engagement in this website.

H2: Website usability has a positive impact on users' engagement in this website.

\subsection{Perceived Information Quality}

Online users increasingly search for online health information. However, Internet is a largely unregulated source that provide inconsistent quality of information [49]. This suggest how important the quality of online health information in such uncertain environment. Higher perceptions of information quality can motivate positive feeling states that may, in turn, lead to increased time spent in the online website [11]. In 
contrast, online experience with lower perceptions of information quality may induce low affective engagement.

When online users perceive higher information quality, users tend to be more involved, and they feel an intrinsic enjoyment $[50,51]$. Previous research has found that an engaging online experience is intrinsically motivating $[52,53]$, and can be influenced by users' involvement in online information gathering.

This study proposes that perceived information quality will positively influence users' engagement in health-related websites, because developing and evaluating a reliable measure of information quality, assists in improving engagement elements, such as attention, affect, aesthetics, novelty, interest, control, feedback, challenge, and motivation [12]. Research on engagement and related constructs supports this assertion. Thus, we propose:

H3: Users' perceived information quality has a positive impact on users' engagement in the website that publish this information.

\section{Research Methodology}

\subsection{Research Design}

An exploratory study was conducted to test the proposed research model. A Webbased survey was utilized to validate the study constructs. Data were collected using a commercially available survey tool; Survey Monkey (www.surveymonkey.com). The survey is divided into three parts. The first part of the survey included questions for the respondents, to check whether they accessed any health-related websites before, and if they searched for online health information. Respondents whose answer is yes, were also asked which health-website they accessed, how many times they accessed these websites, and how long they spent in these websites. Second part of the survey included the measurement items that the study utilized to measure the proposed constructs. The third part of the survey included demographic questions.

A pretest was conducted $(n=25)$. The survey items were pretested to ensure message clarity, believability, and likability. Accordingly, some items were modified or reworded depending on the feedback provided by the respondents. Participants in the pretest were excluded from any further participation in the study.

The survey link was posted to health-related Facebook groups for two months, from Jan to March 2017. When a respondent click the survey link, they were first informed about the study purpose, participants' privacy, and animosity. Then, they were asked to think of a last online experiment of health information search they conducted. Finally, respondents were directed to complete the survey items.

\subsection{Measurement}

Six constructs were measured in this study: website responsiveness, perceived control, two-way communication, website usability, information quality, and engagement. Well established measurements, already used in the literature, were adopted in 
this study. A seven point Likert scale was utilized in the questionnaire, where 1 represents the completely disagreement, and 7 represents the completely agreement, with each item. Final measurement items appear in the Appendix.

\subsection{Participants}

Participants in this study are students from a public university in Jordan. Students found to be the most Internet users [54]. Youth in general found to be the dominant Internet users [55]. Students' online behavior found to be similar to the general population behavior [56].

Moreover, students deemed to be suitable for this research, because the study includes a goal-directed online health information search. Participants who participated in this study have reported some access to health-related websites, searching for online health information.

\subsection{Control Variables}

The following control variables were considered in this study: computer selfefficacy, experience, and gender. Computer self-efficacy is defined as user's belief about his/her ability to perform a specific task using a computer [57]. We used a Ttest, to check if there is a significant difference between users with different levels of computer self-efficacy (high-level and low-level computer self-efficacy).

Users also have different levels of experience in information seeking tasks. A Ttest was used, to check if there is a significant difference between those who have a little experience, and others who have a longer experience with information seeking tasks. Finally, a T-test was used to check if there is a significant difference between male and female participants.

\section{$4 \quad$ Results}

240 completed survey were collected. The percent of female respondents was $64 \%$, while $36 \%$ were males. The T-tests used to check the influence of the control variables showed no significant impact for any of the studied control variable $(\mathrm{P}>0.05)$.

The study used Partial Least Squares (PLS) Structural Equation Modeling (SEM) method to evaluate the hypotheses model. In order to evaluate the properties of the research model; items loading, internal consistency, and discriminant validity were used. Each item's loading should be high on its corresponding construct, at least 0.7 [58]. The entire items' loading in this study exceeded this level, as can be seen in table 1.

Composite reliability scores were used to check for internal consistency. Table 2 shows that composite reliability scores exceeded 0.9 for all constructs. Accordingly, composite reliability considered to be adequate in this study [59], and hence, internal consistency is not a concern in this study. 
For discriminant validity, we used the Square Root of Average Variance Extracted (AVE). For a good discriminant validity, square root of AVE for each construct must be higher than inter-correlations with the other constructs. Accordingly, discriminant validity was not a concern in this study as can be seen in table 2 .

Table 1. Items Loading

\begin{tabular}{|c|c|c|c|c|c|c|}
\hline & Engagement & P. Info Quality & Responsiveness & Control & $\begin{array}{l}\text { Two-way Com- } \\
\text { munication }\end{array}$ & Usability \\
\hline ENG1 & 0.955 & & & & & \\
\hline ENG2 & 0.944 & & & & & \\
\hline ENG3 & 0.944 & & & & & \\
\hline ENG4 & 0.930 & & & & & \\
\hline ENG5 & 0.961 & & & & & \\
\hline ENG6 & 0.963 & & & & & \\
\hline ENG7 & 0.930 & & & & & \\
\hline PQ1 & & 0.888 & & & & \\
\hline PQ2 & & 0.901 & & & & \\
\hline PQ3 & & 0.885 & & & & \\
\hline PQ4 & & 0.920 & & & & \\
\hline PQ5 & & 0.903 & & & & \\
\hline PQ6 & & 0.892 & & & & \\
\hline RSP1 & & & 0.876 & & & \\
\hline RSP2 & & & 0.913 & & & \\
\hline RSP3 & & & 0.938 & & & \\
\hline RSP4 & & & 0.891 & & & \\
\hline Cont1 & & & & 0.715 & & \\
\hline Cont2 & & & & 0.845 & & \\
\hline Cont3 & & & & 0.754 & & \\
\hline Cont4 & & & & 0.781 & & \\
\hline Cont5 & & & & 0.714 & & \\
\hline Comm1 & & & & & 0.846 & \\
\hline Comm2 & & & & & 0.798 & \\
\hline Comm3 & & & & & 0.904 & \\
\hline USB1 & & & & & & 0.922 \\
\hline USB2 & & & & & & 0.949 \\
\hline USB3 & & & & & & 0.940 \\
\hline
\end{tabular}

Results of this study are presented in figure 2. Engagement had an R-Square of 0.783 , meaning that the model explains $78.3 \%$ of the variance in engagement collectively [50]. Path coefficients were all significant as shown in table 3 . All five hypotheses are supported. 
Paper-Health Website Success: User Engagement in Health-Related Websites

Table 2. Internal consistency and discriminant validity

\begin{tabular}{|l|l|l|c|c|c|c|c|}
\hline \multicolumn{9}{|c|}{ Square Root of AVE and inter-construct correlations } \\
\hline \multicolumn{2}{|c|}{ Eng } & P. Qual. & Resp & Cont & Comm & Usab \\
\hline \multicolumn{2}{|c|}{ Comp. Reliability } & & & & & & \\
\hline 0.984 & Eng & 0.947 & & & & & \\
\hline 0.973 & P. Qual. & 0.596 & 0.894 & & & & \\
\hline 0.948 & Resp & 0.551 & 0.582 & 0.905 & & & \\
\hline 0.909 & Cont & 0.354 & 0.481 & 0.382 & 0.884 & & \\
\hline 0.847 & Comm & 0.452 & 0.418 & 0.344 & 0.512 & 0.902 & \\
\hline 0.956 & Usab & 0.552 & 0.574 & 0.552 & 0.476 & 0.534 & 0.937 \\
\hline
\end{tabular}

Table 3. Summary of hypotheses tests

\begin{tabular}{|l|c|c|c|}
\hline & Path Coefficient & t-Value & P Values \\
\hline H1A: Responsiveness $\rightarrow$ Engagement & $0.455^{* *}$ & 3.839 & 0.000 \\
\hline H1B: Control $\rightarrow$ Engagement & $0.508^{* *}$ & 3.912 & 0.000 \\
\hline H1C: Two-way communication $\rightarrow$ Engagement & $0.482^{* *}$ & 3.742 & 0.000 \\
\hline H2: Usability $\rightarrow$ Engagement & $0.464^{* *}$ & 8.774 & 0.000 \\
\hline H3: Perceived Quality $\rightarrow$ Engagement & $0.896^{* * *}$ & 10.498 & 0.000 \\
\hline
\end{tabular}

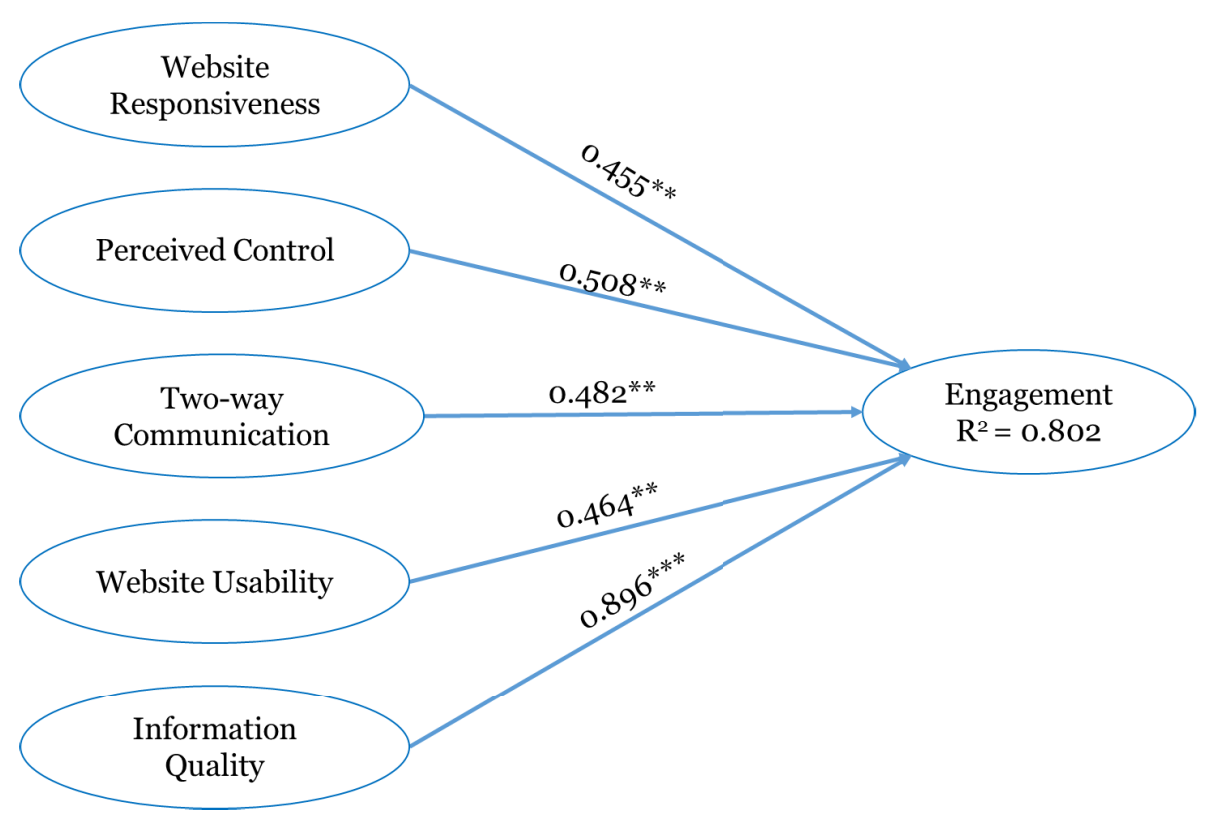

Fig. 2. PLS results 


\section{$5 \quad$ Discussion and Implications}

This research investigates the impact of three main factors on users' engagement in health-related websites. First factor is related to the interaction between the health website and its users; website interactivity. Second factor is related to the healthrelated website itself; website usability. The third factor is related to the website content; information quality.

The results of this study proved that interactive websites engaged users more the un-interactive websites. Responsive, controllable, and interactive websites, engage users in these websites more than other websites. Results also proved that users who explored a usable website were engaged in these websites more than other users who explored an unusable website. Finally, users who perceived online published information in a health-related website as a high-quality information, were also more engaged, comparing to other users who perceived such information as a low-quality information.

The results are consistent with prior research, about the significance of website interactivity, and its impact on users' engagement. Based on the flow theory, users with higher perceptions of control when exploring a website, reported higher users' involvement when navigating this website [28]. This control can lead to increased pleasure and flow [14], and hence, increased engagement. Website interactivity, where users find quick and interactive responses to their questions and inquiries, was proved to improve website revisit intention, suggesting that engaged users have higher revisit intention.

Website usability positively influences users' engagement. This was also compatible with prior research. Prior research has found that users who explore a usable system made less errors, and experienced higher accuracy and increasing computer usage [60]. These factors were found, in turn, to be connected to users' engagement [38]. Most prior research in e-commerce found a strong connection between e-commerce website's usability and purchase intention [61, 62]. Prior research also proved a relationship between website usability, and emotional state of online users, like arousal and pleasure.

Results of this research proved that online users, who highly rated the quality of information published in health-related websites, feel more engaged in these websites. With the information explosion on the Internet, and substantial quantity of online health information sources, online users need more reasons to trust the information quality, and be more engaged in its source. This is especially true when dealing with more sensitive information, like health information.

Among factors related to: the interaction between the health-related website and its users, the website itself, and the website content, results showed that factors related to the website content, perceived information quality $(\beta=0.896, \mathrm{P}<.000)$, is the strongest predictor of engagement in health-related websites. Meaning that users of healthrelated websites are most motivated to be engaged when they have less concerns about the quality of health information. Information quality influenced users' engagement more than website interactivity and usability do. This is true because health 
information quality is more sensitive comparing to any other type of online information. Low-quality health information can be harmful.

Investigating health-related website's success, represented in engagement in health-related websites, is one of the contributions of this research for practice. This research provides deep insights for online health service providers, who must be interested in understanding the factors affecting users' engagement in their websites.

Using results provided by this research, designers of health-related websites can learn that when the website, website managers, and fellow members are more responsive to other users of this website, they would be more engaged in it. Alternatively, low interactive and low responsive websites would less engage users. Consequently, designers of these websites would include contents that support interactivity in their designs. Example of these designs are online chat features or interactive discussion boards.

\subsection{Limitations and Future Research}

This research aimed to investigate the success of health-related websites. Toward this purpose, the research identified a thorough list of factors that might influence engagement in health-related website. However, in addition to engagement, other factors might represent website's success as well. Example of these factors are: trust, intention to use, satisfaction, and design quality. Future research is recommended to conduct an inductive approach, that provide a comprehensive list of factors that represent website success.

\subsection{Conclusions}

This research aimed to investigate the success of health-related websites. Toward this purpose, the research identified a thorough list of factors that might influence engagement in health-related website. However, in addition to engagement, other factors might represent website's success as well. Example of these factors are: trust, intention to use, satisfaction, and design quality. Future research is recommended to conduct an inductive approach, that provide a comprehensive list of factors that represent website success.

\section{References}

[1] Miller, L. M. S., \& Bell, R. A. (2012). Online health information seeking: the influence of age, information trustworthiness, and search challenges. Journal of aging and health, 24(3), 525-541. https://doi.org/10.1177/0898264311428167

[2] Liu, Y., \& Shrum, L. J. (2002). What is interactivity and is it always such a good thing? Implications of definition, person, and situation for the influence of interactivity on advertising effectiveness. Journal of advertising, 31(4), 53- https://doi.org/10.1080/009133 $\underline{67.2002 .10673685}$ 
[3] Orlikowski, W.J. (2000). Using Technology and Constituting Structures: A Practice Lens for Studying Technology in Organizations. Organization Science, Vol. 11, No. 4, pp. 404428. https://doi.org/10.1287/orsc.11.4.404.14600

[4] Palmer, J. W. (2002). Web site usability, design, and performance metrics. Information systems research, 13(2), 151-167. https://doi.org/10.1287/isre.13.2.151.88

[5] Mebrate, T. W. (2010). A framework for evaluating academic website's quality from students' perspective. Delft University of Technology, Delft.

[6] Cunliffe, D. (2000). Developing usable Web sites-a review and model. Internet Research, 10(4), 295-308. https://doi.org/10.1108/10662240010342577

[7] Jacques, R., Preece, J. \& Carey, T. (1995). Engagement as a design concept for hypermedia. Canadian Journal of Educational Communications 24(1), pp.49-59.

[8] Yi, C., Jiang, Z., \& Benbasat, I. (2015). Enticing and Engaging Consumers via Online Product Presentations: The Effects of Restricted Interaction Design. Journal of Management Information Systems, 31(4), 213-242. https://doi.org/10.1080/07421222.2014. 1001270

[9] Stvilia, B., Mon, L., \& Yi, Y. J. (2009). A model for online consumer health information quality. Journal of the American Society for Information Science and Technology, 60(9), 1781-1791. https://doi.org/10.1002/asi.21115

[10] Eysenbach, G., Powell, J., Kuss, O., \& Sa, E. R. (2002). Empirical studies assessing the quality of health information for consumers on the world wide web: a systematic review. Jama, 287(20), 2691-2700. https://doi.org/10.1001/jama.287.20.2691

[11] Imlawi, J., Gregg, D., \& Karimi, J. (2015). Student engagement in course-based social networks: The impact of instructor credibility and use of communication. Computers \& Education, 88, 84-96. https://doi.org/10.1016/j.compedu.2015.04.015

[12] O'Brien, H. L., Toms, E. G., Kelloway, E. K., \& Kelley, E. (2008). Developing and evaluating a reliable measure of user engagement. Proceedings of the American Society for Information Science and Technology, 45(1), 1-10. https://doi.org/10.1002/meet.2008. 1450450258

[13] Eroglu, S. A., Machleit, K. A., \& Davis, L. M. (2003). Empirical testing of a model of online store atmospherics and shopper responses. Psychology \& Marketing, 20(2), 139150. https://doi.org/10.1002/mar.10064

[14] Ariely, D. (2000) "Controlling the Information Flow: Effects on Consumers' Decision Making and Preferences," Journal of Consumer Research (27) 2, pp. 233-248. https://doi.org/10.1086/314322

[15] Steuer, J. (1992) "Defining virtual reality: Dimensions determining telepresence," Journal of Communication (42) 4, pp. 73. https://doi.org/10.1111/j.1460-2466.1992.tb00812.x

[16] Wu, G., \& Wu, G. (2006). Conceptualizing and measuring the perceived interactivity of websites. Journal of Current Issues \& Research in Advertising, 28(1), 87-104. https://doi.org/10.1080/10641734.2006.10505193

[17] Mollen, A., \& Wilson, H. (2010). Engagement, telepresence and interactivity in online consumer experience: Reconciling scholastic and managerial perspectives. Journal of business research, 63(9), 919-925. https://doi.org/10.1016/j.jbusres.2009.05.014

[18] Cui, N., Wang, T., \& Xu, S. (2010). The influence of social presence on consumers' perceptions of the interactivity of web sites. Journal of Interactive Advertising, 11(1), 36-49. https://doi.org/10.1080/15252019.2010.10722176

[19] Lowry, P. B., Spaulding, T., Wells, T., Moody, G., Moffit, K., \& Madariaga, S. (2006). A theoretical model and empirical results linking website interactivity and usability satisfaction. In System Sciences, 20HICSS'Proceedings of the 39th Annual Hawaii International Conference on (Vol. 6, pp. 123a-123a). IEEE. https://doi.org/10.1109/HICSS.2006.33 
[20] Wu, J. J., \& Chang, Y. S. (2005). Towards understanding members' interactivity, trust, and flow in online travel community. Industrial Management \& Data Systems, 105(7), 937954. https://doi.org/10.1108/02635570510616120

[21] Sicilia, M., Ruiz, S., \& Munuera, J. L. (2005). Effects of interactivity in a web site: The moderating effect of need for cognition. Journal of advertising, 34(3), 31-44. https://doi.org/10.1080/00913367.2005.10639202

[22] Wu, G. (1999). Perceived interactivity and attitude toward web sites. In Proceedings of the conference-American Academy of Advertising (pp. 254-262). American Academy of Advertising.

[23] Ghose, S., \& Dou, W. (1998). Interactive functions and their impacts on the appeal of Internet presence sites. Journal of Advertising research, 38, 29-44.

[24] Dubelaar, C., Leong, M., \& Alpert, F. (2003). Impact of interactivity on the stickiness of online gift stores. Journal of Asia Pacific Marketing, 2(2), 22-41.

[25] Green, D. T., \& Pearson, J. M. (2011). Integrating website usability with the electronic commerce acceptance model. Behaviour \& Information Technology, 30(2), 181-199. https://doi.org/10.1080/01449291003793785

[26] Mpinganjira, M. (2015). An Investigation Of Perceived Service Quality In Online Shopping: A Hierarchical Approach. Journal of Applied Business Research, 31(1), 115. https://doi.org/10.19030/jabr.v31i1.9050

[27] Yoo, C. W., Kim, Y. J., \& Sanders, G. L. (2015). The impact of interactivity of electronic word of mouth systems and E-Quality on decision support in the context of the emarketplace. Information \& Management, 52(4), 496-505. https://doi.org/10.1016/ j.im.2015.03.001

[28] Novak, T. P., Hoffman, D. L., \& Yung, Y. F. (2000). Measuring the customer experience in online environments: A structural modeling approach. Marketing science, 19(1), 22-42. https://doi.org/10.1287/mksc.19.1.22.15184

[29] Chai, S., Das, S., \& Rao, H. R. (2011). Factors affecting bloggers' knowledge sharing: An investigation across gender. Journal of Management Information Systems, 28(3), 309-342. https://doi.org/10.2753/MIS0742-1222280309

[30] Cheung, C. M., Lee, M. K., \& Rabjohn, N. (2008). The impact of electronic word-ofmouth: The adoption of online opinions in online customer communities. Internet Research, 18(3), 229-247. https://doi.org/10.1108/10662240810883290

[31] Madu, C.N. and Madu, A.A. (2002), "Dimensions of e-quality", International Journal of Quality and Reliability Management, Vol. 19 No. 3, pp. 246-58. https://doi.org/10.1108/ 02656710210415668

[32] Han, S., Min, J., \& Lee, H. (2015). Antecedents of social presence and gratification of social connection needs in SNS: a study of Twitter users and their mobile and non-mobile usage. International Journal of Information Management, 35(4), 459-471. https://doi.org/10.1016/j.ijinfomgt.2015.04.004

[33] Green, D. and Pearson, J.M., (2006). Development of a website usability instrument based on ISO 9241-Journal of Computer Information Systems, 47 (1), 66- 72.

[34] Rahman, M. S., \& Ahmed, S. Z. (2013). Exploring the factors influencing the usability of academic websites A case study in a university setting. Business information review, 30(1), 40-47. https://doi.org/10.1177/0266382113482557

[35] Nielsen, J. (2016). Usability 101: Introduction to usability. Available at: https://www.nngroup.com/articles/usability-101-introduction-to-usability/ (accessed January 4,2016$)$.

[36] Tarafdar, M., \& Zhang, J. (2005). Analyzing the influence of web site design parameters on web site usabilityInformation Resources Management Journal, 18(4), 62. 
[37] Nielsen, J. (2000). Designing Web Usability New Riders Publishing. Indianapolis IN USA.

[38] Imlawi, J., \& Gregg, D. (2014). Engagement in online social networks: The impact of selfdisclosure and humor. International Journal of Human-Computer Interaction, 30(2), 106125. https://doi.org/10.1080/10447318.2013.839901

[39] Nantel, J., \& Senecal, S. (2009). The effect of counterproductive time on online task completion. International Journal of Internet Marketing and Advertising, 5(4), 246-259. https://doi.org/10.1504/IJIMA.2009.027809

[40] Davis, F. (1989) Perceived Usefulness, Perceived Ease of Use, and User Acceptance of Information Technology, MIS Quarterly 13 (3), pp. 319-340. https://doi.org/10.2307/249008

[41] Teo, H. H., Oh, L. B., Liu, C., \& Wei, K. K. (2003). An empirical study of the effects of interactivity on web user attitude. International Journal of Human-Computer Studies, 58(3), 281-305. https://doi.org/10.1016/S1071-5819(03)00008-9

[42] Mummalaneni, V. (2005). An empirical investigation of Web site characteristics, consumer emotional states and on-line shopping behaviors. Journal of Business Research, 58(4), 526-532. https://doi.org/10.1016/S0148-2963(03)00143-7

[43] Yang Z., y Fang X. (2004): Online Service Quality dimensions and their relationships with satisfaction. International Journal of Service Industry Management 15 (3), pp. 3023https://doi.org/10.1108/09564230410540953

[44] Yang Z., Cai, S., Zhou, Z. and Zhou, N. (2005) Development and validation of an instrument to measure user perceived service quality of information presenting web portals. Information \& Management 42 (4), pp. 575-589. https://doi.org/10.1016/S03787206(04)00073-4

[45] Flavián, C., Guinalíu, M., \& Gurrea, R. (2006). The role played by perceived usability, satisfaction and consumer trust on website loyalty. Information \& Management, 43(1), 1-14. https://doi.org/10.1016/j.im.2005.01.002

[46] Casaló, L. V., Flavián, C., \& Guinalíu, M. (2008). The role of satisfaction and website usability in developing customer loyalty and positive word-of-mouth in the e-banking services. International Journal of Bank Marketing, 26(6), 399-417. https://doi.org/10.1108/ 02652320810902433

[47] Kim, E. B., \& Eom, S. B. (2002). Designing effective cyber store user interface. Industrial Management \& Data Systems, 102(5), 241-251. https://doi.org/10.1108/02635570 210428276

[48] Maditinos, D. I., \& Theodoridis, K. (2010). Satisfaction determinants in the Greek online shopping context. Information Technology \& People, 23(4), 312-329. https://doi.org/10.1108/09593841011087789

[49] Fahy, E., Hardikar, R., Fox, A., \& Mackay, S. (2014). Quality of patient health information on the Internet: reviewing a complex and evolving landscape. Australasian Medical Journal, 7(1). https://doi.org/10.21767/AMJ.2014.1900

[50] Agarwal, R., \& Karahanna, E. (2000). Time flies when you're having fun: Cognitive absorption and beliefs about information technology usage. MIS quarterly 24(4), 665-694. https://doi.org/10.2307/3250951

[51] Koufaris, M. (2002). Applying the technology acceptance model and flow theory to online consumer behavior. Information systems research, 13(2), 205-223. https://doi.org/10.1287/ isre.13.2.205.83

[52] Jiang, Z., \& Benbasat, I. (2007). Research note-investigating the influence of the functional mechanisms of online product presentations. Information Systems Research, 18(4), 454470. https://doi.org/10.1287/isre.1070.0124 
[53] Suh, K. S., \& Lee, Y. E. (2005). The effects of virtual reality on consumer learning: an empirical investigation. Mis Quarterly 29(4), 673-697. https://doi.org/10.2307/25148705

[54] Lim, K. H., Sia, C. L., Lee, M. K., \& Benbasat, I. (2006). Do I trust you online, and if so, will I buy? An empirical study of two trust-building strategies. Journal of management information systems, 23(2), 233-266. https://doi.org/10.2753/MIS0742-1222230210

[55] McGann, R. (2005). Most active Web users are young, affluent. ClickZ Network, http://www. clickz. com/3455741.

[56] Thakur, R., \& Summey, J. H. (2007). e-Trust: Empirical insights into influential antecedents. Marketing Management Journal, 17(2), 67-80.

[57] Venkatesh, V. (2000). Determinants of perceived ease of use: Integrating control, intrinsic motivation, and emotion into the technology acceptance model. Information systems research, 11(4), 342-365. https://doi.org/10.1287/isre.11.4.342.11872

[58] Hulland, J. (1999). Use of partial least squares (PLS) in strategic management research: A review of four recent studies. Strategic management journal 20(2), 195-204. https://doi.org/10.1002/(SICI)1097-0266(199902)20:2<195::AID-SMJ13>3.0.CO;2-7

[59] Hair, J. F., Anderson, R. E., Babin, B. J., \& Black, W. C. (2010). Multivariate data analysis: A global perspective (Vol. 7). Upper Saddle River, NJ: Pearson.

[60] Lecerof, A., \& Paternò, F. (1998). Automatic support for usability evaluation. Software Engineering, IEEE Transactions on, 24(10), 863-888. https://doi.org/10.1109/32.729686

[61] Hill, A. (2001), Top 5 Reasons Your Customers Abandon Their Shopping Carts. Ziff Davis Smart Business for the New Economy, 14(3), pp. 80-85.

[62] Becker, S. A., \& Mottay, F. E. (2001). A global perspective on web site usability. IEEE software, 18(1), 54-61. https://doi.org/10.1109/52.903167

[63] Tongxiao (Catherine) Zhang, Agarwal, R., \& Lucas Jr, H. C. (2011). The value of ITenabled retailer learning: personalized product recommendations and customer store loyalty in electronic markets. Mis Quarterly, 35(4), 859-881. https://doi.org/10.2307/41409964

[64] Webster, J., \& Ho, H. (1997). Audience engagement in multimedia presentations. ACM SIGMIS Database, 28(2), 63-77. https://doi.org/10.1145/264701.264706

[65] Nicolaou, A. I., \& McKnight, D. H. (2011). System design features and repeated use of electronic data exchanges. Journal of Management Information Systems, 28(2), 269-304. https://doi.org/10.2753/MIS0742-1222280210

[66] Corritore, C., Kracher, B. and Wiedenbeck, S. (2003). On-line trust: evolving themes, a model, International Journal of Human-Computer Studies 58, pp.737-758. https://doi.org/10.1016/S1071-5819(03)00041-7

\section{$7 \quad$ Author}

Jehad Imlawi is Assiatant professor at Al Albayt University, IT School, Information Systems Department, Mafraq, Jordan.

Article submitted 29 March 2017. Published as resubmitted by the authors 15 May 2017. 


\section{Appendix A}

\section{Measurements and Items}

\begin{tabular}{|c|c|c|}
\hline Construct & Items & Source \\
\hline $\begin{array}{l}\text { Perceived Responsive- } \\
\text { ness }\end{array}$ & $\begin{array}{l}\text { - The Web site is effective in gathering visitors' feedback. } \\
\text { - This Web site facilitates two-way communication between the } \\
\text { visitors and the site. } \\
\text { - The Web site makes me feel it wants to listen to its visitors. } \\
\text { - The Web site gives visitors the opportunity to talk back. }\end{array}$ & [18] \\
\hline $\begin{array}{l}\text { Perceived Control over a } \\
\text { Web site }\end{array}$ & $\begin{array}{l}\text { - While I was on the Web site, I was always aware where I was. } \\
\text { - While I was on the Web site, I always knew where I was going. } \\
\text { - I was delighted to be able to choose which link and when click. } \\
\text { - I feel that I have a great deal of control over my visiting experi- } \\
\text { ence at this Web site. } \\
\text { - While I was on the Web site, I could choose freely what I wanted } \\
\text { to see. }\end{array}$ & [18] \\
\hline Two-way communication & $\begin{array}{l}\text { - When I share information through this website, I believe that my } \\
\text { questions will be answered in the future. } \\
\text { I believe that websites manager I interact with would help me if I } \\
\text { was in need. } \\
\text { - When I share my knowledge and information through this web- } \\
\text { site, I expect some other users to respond when I am in need. }\end{array}$ & [29] \\
\hline Website usability & $\begin{array}{l}\text { - The website was very user-friendly. } \\
\text { - The website was easy to use. } \\
\text { - The website was well organized. }\end{array}$ & [63] \\
\hline Engagement & $\begin{array}{l}\text { - The Web site kept me totally absorbed in the browsing. } \\
\text { - The Web site held my attention. } \\
\text { - The Web site excited my curiosity. } \\
\text { - The Web site aroused my imagination. } \\
\text { - The Web site was fun. } \\
\text { - The Web site was intrinsically interesting. } \\
\text { - The Web site was engaging. }\end{array}$ & {$[64]$} \\
\hline $\begin{array}{l}\text { Perceived information } \\
\text { quality }\end{array}$ & $\begin{array}{l}\text { - The website provides up-to-date information with regard to } \\
\text { transactions. } \\
\text { - The data this website provides are never outdated. } \\
\text { - I feel satisfied with the data accuracy of the website. } \\
\text { - Data provided by this website are completely error-free } \\
\text { - The information content of the website meets my needs. }\end{array}$ & {$[65]$} \\
\hline
\end{tabular}

